\title{
A Study of solution in training application-oriented talents about general education ${ }^{1}$
}

\author{
REN Jia \\ Evaluation and teaching quality supervision office \\ Xi'an Fanyi University, \\ Xi'an, Shaanxi, 710105, China \\ 505410068@qq.com
}

\begin{abstract}
The paper analyzes the necessity of general education in the applied talents training, the problem about the general course in newly-built undergraduate colleges is analyzed, the reform ideas of teaching curriculum in general education come forward, the direction of course teaching in newly-built undergraduate colleges.
\end{abstract}

Keywords—-general education, training of application-oriented talent, new built undergraduate colleges, solution.

\section{INTRODUCTION}

General education is one of the important part of the applied talents training, has unique role in cultivating college students' all-round development. He Qinsi, a former rector of university of Chicago said: "if there is no general education, we should not be able to construct a good university." Pan Mao-yuan, Founder of China's higher education pointed out application-oriented talents is not study with applying theoretical knowledge, on the contrary, application-oriented talents not only play a role in application of knowledge but also had a profound effect in theory to develop innovation and applied research aspects.

In today's rapid development of information technology, contending of all kinds of values, peripheral discipline, fuzzy disciplines emerge in endlessly, all kinds of environment, population, resources and cultural conflict problem appeared, but a single subject cannot solve the complex problems. the key problems of new-built undergraduate college is be healthy and continued development with analyzing the problems of implement general education in new-built undergraduate colleges and exploring for effective solution of teaching general curriculums in new-built undergraduate colleges.

\section{A. General education}

In 1829, Packard, a professor in United States, put forward the concept of general education and thought that general education is teaching of knowledge to student before studying professional knowledge. General education is to give students wider knowledge, a wider field of vision. General education is defined as that the part of education was focus on the students in their whole education as a citizen for the first time in Harvard University. General education contains a natural science, social science and humanities knowledge, achieves ascension the thinking ability of the students through training their thinking of logical, imagination and critical thinking. Chris Kaman, a professor of Columbia College, thinks that general education is a kind of education to provide the behavior of the common core knowledge, motivation and attitude.

The hawthorne, Joan AnNiKe its and Thomas Dean found through the survey that students get to know general education being as the important foundation of professional education and teachers have been general education as a part of professional education. Columbia University use core general education, general courses are divided into several different ways for students to study in Massachusetts institute of technology. Foreign universities usually choose high levels professor to teach general education and curriculum teaching assistant with doctoral and master's graduate students and usually choose small-class teaching, classical reading and deep discussion in teaching method.

General education played a unique role of university undergraduate education in the United States, General education was the basic component of the alternative complement with professional education each other in the system of undergraduate education, General education had been unprecedented consolidated and strengthened in American university education through constant development.

\section{B. New-built undergraduate colleges}

Since 21 st century, the famous universities in the domest had establish general education elective courses, "Yuan Pei" plan of Peking University was begin in 2001, Tsinghua university, Fudan university, Nanjing university, zhejiang university, Huazhong university of science and technology, Shanghai jiaotong university, wuhan university, Sun Yat-sen university were stepping into queue of general education practice mode, implemented a solid foundation for general education in our country. To improve the capacity of college students and graduate employment problem the personnel training quality in common colleges and universities at present situation, many experts and scholars have conducted a lot of exploration and research related to general education.

\footnotetext{
${ }^{1}$ The research was sponsored by the science research projects of education department in Shaanxi provincial government (Project No. 16JK2078) and key project of education department in Shaanxi provincial government (Project No.13BZ69).
} 
According to data display in 2016, the number of colleges established newly undergraduate have reached 463 in China, close to half of the country's ordinary undergraduate colleges and universities. Newly established undergraduate colleges have become an important member to solve the problem of difficulty to go to College. college established newly undergraduate became the college in general by the merger, restructuring, upgrading, the predecessor. To the old college, these new local colleges have short time and fewer experience for running a school, teaching staff, the general knowledge and understanding of educational problems more prominent. Although part of new local colleges set up general education curriculum, there is not conducive to implement of general education in ideology, system environment, teaching method, content management, curriculum, training, applied talents, the teach quality of general education still need Constantly improve.

- General education is conducive to cultivate talents of comprehensive qualities and good personality. General education is not only to teach students how to do things, but also to teach them how to be human and to cultivate the full meaning of people. The characteristics of the so-called "full sense of the word" of is comprehensive application of much ability such as respect and fear of life, a taste of life and thinking, the choice of values and the pursuit of life. General education is the starting point to respect and satisfy the essential needs of human beings and to promote the long-term development of human beings. Therefore, it's fair to say that general education is to cultivate the kind of person who can work hard and have a big life goal.

- General education is conducive to cultivate the innovative ability of applied talents. Early specialization education in college can easily lead to restrain of students' vision and thinking. According to Training requirements of thick foundation and wide caliber in application-oriented talents, the knowledge structure of general education focus on cultivating students' good thinking and methodology, and emphasize knowledge integration and expand their field of vision, which helps to build good knowledge structure of application-oriented talents.

General education can cultivate their ability of active learning through students' curiosity. The students have the good cultural quality through cultivating of the solid foundation knowledge study and the psychological quality, which is also the basic requirement of application-oriented talents.

- The problem analysis of General education.According to the requirements of the documents, guidance of the transition on ordinary undergraduate colleges issued by the ministry of education, the national development and reform commission, ministry of finance, the newly built undergraduate colleges have joined to the array of transformation on training application-oriented talents, colleges of the transformation development actively explore double type teacher training, promote college tutor system and the enterprise training of young teachers, the purpose is to train more application-oriented talents for the society. General education has important significance for training application-oriented talents, the general education curriculums in the newly-built undergraduate colleges cannot get attention, the reason is due to the limitations of knowledge and practice.

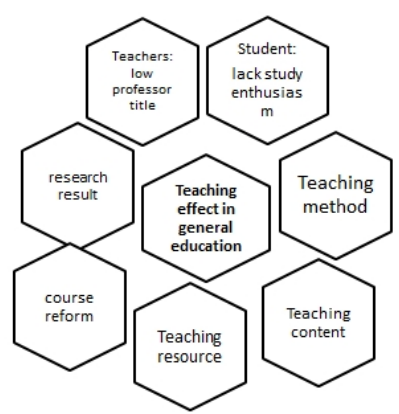

Figure 1. Influence factor of general education teaching effect

- Understanding deviation of general education. Known as general education, the basic education, which is not related to students' future employment skills, is not a necessity for survival for students to work in the future. Many people think that the main problem in newly built college is teaching students solving practical problems by professional knowledge and skills. However, general education can teach the students basic knowledge, skills, ideas, emotion, culture education, let the students understand the different knowledge and the wisdom of different disciplines, students learn wisdom in digest and mental training promotion from tool person trained professional education and vocational training to a fully developed person to society.

General courses lie in an important position in college teaching, the newly built undergraduate colleges should give students enough professional education of humanities and social sciences by their own subject features and pay attention to the cross penetration and links in the liberal arts. But as the deviation of supply and demand in college employment market, the students lack motivation of learning a curriculum, students' learning performance of a curriculum, such as reluctantly, negative and lack of enthusiasm, even as part of the newly built undergraduate colleges in talent-developing plans reduce class time in general education.

- The course system of general education needs to be perfected. Higher education in Chinese overemphasis on science and neglect of arts, lacks of enough recognition in the humanities education, ignores culture of the general education, such as social responsibility, health, the broad mind and the humanities. Equate general education with humanities education, simply 
increase literature training course, ignore curriculum system integrity and fusion in general education courses, Even some colleges act in opposition to general education and professional education, general education as non-professional, nonutilitarian education. In fact, connotation and coverage of general education is much wider than professional education, and a small part of general education is the basic part of professional education.

- The results of general educational reform are narrow. At present, the course teaching of general education is still in the scattered stage, the effect of combination boxing is not achieved. The teaching resources development of general education course is also in the simple cooperation stage, and the innovation in the construction of the teaching resource sharing is slow. Under the influence of MOOC and SPOC, improving the teaching effect of general education curriculum has become urgent need, newly built undergraduate colleges have realized the importance of general education curriculum reform, and actively organize teachers to carry out the teaching method innovation and the reform of teaching mode, but some teachers in the study of general educational reform project attaches great importance to the project and ignore the research process.

- The teaching effect of general courses is not ideal.With the request of connotation construction and improve the quality, teaching curriculum requirements of the newly-built undergraduate colleges haven't realize the hierarchical classification teaching, even with the teaching mode of different professional in a classroom, the number of students is nearly 200 in a classroom, teaching effect of some general education curriculum is very bad because different students' ability to receive is different, lack of learning enthusiasm and initiative in a large-scale class teaching.

\section{PATH OF GENERAL EDUCATION IN TRAINING APPLICATION-ORIENTED TALENTS}

In order to adapt to the needs of the transformation development in newly built college, course construction put forward as the important thing such as optimize the teaching content, innovation of teaching methods, creating a good teaching team, Scientific research promotes classroom teaching and professional development of young teachers, improve the effect of teaching curriculum, trains the student to have a solid theoretical foundation for knowledge, and improve the students' ability to apply knowledge to solve practical problems as the goal.

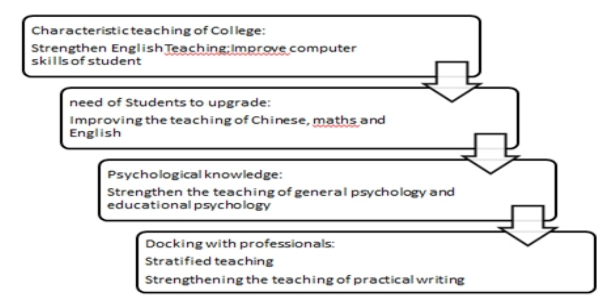

Figure 2. Solution of training application-oriented talents in general education

\section{A. Teaching team construction is the key of teaching quality in general education curriculum.}

In the process of training application-oriented talents in newly built undergraduate colleges, the students need teachers with enterprise experience, the rude of teachers team construction is adhere to culture, introduce, borrow wisdom and stability, actively explore the subject head by associate professor, head of teaching curriculum by associate professor and lecturer, the good teaching team with moral cultivation, high teaching level, good scientific research ability is built by the collective lesson preparation, speaking lesson before class and build teaching resources of private cloud network, teachers' comprehensive literacy is promoted by the visiting study, mentoring young teacher credentials the exercise, enterprise excise, scientific quantification assessment.

\section{B. The curriculum system is the core of general education quality.}

Curriculum construction is the assurance of teaching quality in general education, also an important way to improve the teaching quality of general education curriculum. The newly built college should actively introduce the online open course platform, and invest the funds to encourage young teacher construction of online open courses. Ten projects will be carried out reform and innovation on the curriculum construction, teaching syllabus and teaching materials, knowledge system and teaching content, teaching methods, online open course construction etc.

\section{The teaching model of general education curriculums.}

Talent-developing plans directly determines a high efficiency personnel training specification, new built undergraduate colleges should pay attention to the development and perfection of personnel training programs for question of the current employment market demand, from implementation of the party's education, strengthen the core values education, carry forward noble education, construction teaching content features of general education platform and professional education platform and professional direction module, fully reflecting the teaching content characteristics of basic knowledge, professional knowledge and technical knowledge, strengthen students social responsibility, innovation spirit, practical ability as the key task to the whole process of education and teaching,

The general education adheres to the characteristic teaching mode of the school, adopts the classified teaching according to the acceptance ability of different professional students, and applies the teaching reform achievements to the talent training scheme. 


\section{Teaching methods, evaluation model actively explored}

The newly built universities should encourage teachers to innovate teaching methods, to carry out teaching method of heuristic, discussion, participatory, situational teaching etc. the dominant position of students learning, the subjects topic of autonomous learning courses chosen by students and teachers, multiple learning models, the training guidance of learning strategies and methods, students' critical thinking and innovative ability promote the development of students' personality. In normal teaching practice, actively promote case teaching, students' practice and students' extra-curricular activity, actively explore the process assessment and paperless examination course evaluation model.

In normal teaching and management, actively promote the network interactive platform of teaching resources through network tools such as WEIYUN, WECHAT and QQ, serve as a mobile network platform for teachers' teaching materials sharing, students' electronic assignments, teacher answering questions. Students need to quickly land by QQ, mobile phone number, any one of net tools.

\section{E. The integration of teaching and research is an important link in promoting teachers' ability}

Teaching is the first task of ordinary college, teachers' teaching level determines the teaching effect, scientific research is necessary of the teacher professional development. scientific research is also a teacher professional title of the mandatory requirements. Scientific research can help teachers to improve the depth of teaching, the integration of teaching and research can promote each other. Newly built colleges should strictly grasp classroom teaching quality engineering, pay attention to teachers' scientific research and teaching reform projects, actively play the role of senior professional teacher on help and effect of young teachers, explore the teaching reform and general education effect, set up scientific research team and senior professional research team.

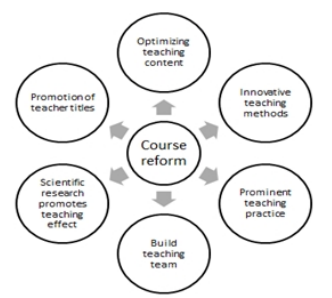

Figure 3. Reform content of general education course

\section{CONCLUSIONS}

General education curriculum is a good way to self-knowledge for college students and a multi curriculum group for students. it will become general education as an education of modern civilized people through cultivation of students' humanistic quality, pay attention to the harmonious development of students' morality, emotion and reason, emphasize the fusion of knowledge, molding sound personality, make students all-round development. New undergraduate colleges combine general education with the construction of first-class college and first-class professional, according to the continuous improvement of teaching quality to strengthen the connotation construction, in order to help students improve self-cultivation, distinguish right and wrong, learn to be a person, learn to work, play a good foundation through general education courses. In general education courses, by curriculum construction, teaching reform, the second classroom, guide students to active learning, enhance students' spirit of collaboration, develop students' potential, meet the sustainable development of students requirements, to cultivate students' ability and quality in the first place, to cultivate applied talents assume a good foundation.

\section{REFERENCES}

[1] MENG Weiqing, HUANG Wei. System dilemma and outlet of general education in Chinese Universities [J].International journal of Chinese education, 2013.8(34)-4:46-50.

[2] Li Manli. Reflection on the construction of general education idea and system in Chinese Universities [J].Peking university education review, 2006(3). 1995-2005.I.S. Jacobs and C.P. Bean, "Fine particles, thin films and exchange anisotropy," in Magnetism, vol. III, G.T. Rado and H. Suhl, Eds. New York: Academic, 1963, pp. 271-350.

[3] LEI Hu, REN Jia, Yin Shuahua. Research of Evaluation System about computer basic teaching in newly built Universities [J].Computer education,2015,2,25:63-67.

[4] Gaff J. G., et al. Handbook of Undergraduate Curriculum: A Comprehensive Guide to Purposes, Structures, Practices, and Change [M].San Fran-cisco: Jossey Bass Publisher, 1997:96-97.

[5] A S. Packard. "The Substance of Two Reports of the Faculty of Amherst College to Board of Trustees, with The Doings of the Board thereon", North American Review, vol128, 1829,p.300.

[6] M.dacin, M.Ventresca \& B. Beal. The embeddedness of organisations:Dialogue \& Directions. Journal of management,1999,Vol.25(3):pp.317-356.

[7] James O. Freedman. Liberal Education and the Public interest, lowa city: University of lowa Press,2003:1-24. 